UDC 174 DOI 10.22448/AMJ.2017.4.9-9

\title{
SOME ETHICAL PROBLEMS OF MODERN MEDICINE
}

\section{A.I. Kovalenko, O.A Sharshova}

In connection with the development of scientific and technological progress and the unfolding democratic processes in society, the content of medicine and interpersonal relations in the health care system are radically changing. High technology allows you to give life through artificial insemination, change its quality parameters (genetic engineering, transsexual surgery), and push the boundaries of life, pushing the time of death (resuscitation, transplantology). However, in the sphere of human relations within the framework of old ethical norms and legislative acts this is not always appreciated by normal phenomena. Therefore, modern medical capabilities need to create a new moral and legal framework capable of forming a bioethical worldview of doctors and patients.

Let's note some problem situations arising in medical practice.

In recent years, there has been a significant specialization and differentiation of medical knowledge. At present, about 300 specialties have been formed in medicine. Objectively, doctors-specialists focus on individual local pathological processes, as a result of which the perception of the patient as an individual begins to lose. This leads to a decrease in the social essence and deformation of the ethical behavior of the doctor. Often, diagnostic decisions and methods of treatment of a patient require collegial discussion with several specialists. Sometimes narrow specialists shy away from solving complex clinical cases. Themanagementofthepatientisundertaken bytheattending physician, whosecompetencesaresometimeslimited.

Under the big doubt in society, the principle of justice in medical care is put. High-tech treatment requires high costs and at a price is expensive for the patient. The state is trying to somehow mitigate the situation by allocating quotas. But their number can not meet the needs of the population and medical assistance is not available. The situation is aggravated by the fact that numerous private clinics often prescribe an extensive examination and high-priced medicines that are not always justified by necessity, but more often dictated by commercial interest.

Many ethical problems in medicine have given rise to the development of the human rights movement, transformed into the rights of the patient. Traditionally, the prevailing principle of paternalism began to give way to the principle of cooperation, in which, along with professional decisions of the doctor, the opinion of the patient himself, his value priorities is of great importance. Essentially, the doctor and the patient become partners in the treatment process, and for this it is necessary to establish trust between the doctor and the patient. The patient should make a voluntary and informed choice based on complete and reliable information about the nature and goals of the proposed treatment, the significant risk associated with it and the proposed alternatives to one type of treatment. This approach greatly increases the moral responsibility of both the doctor and the patient for the final result.

But the most acute moral conflicts arise where the human life arises and stops, and therefore the most intense are the discussions about abortion, artificial reproduction of man and euthanasia. The decision to abortion is always a difficult moral choice. What is he hiding? The danger to the health of women and the killing of the fetus, or it is a means of regulating the birth rate. If so, then this is a very cruel tool. Experts believe that it is abortion most often leads to complications that cause secondary infertility. A woman loses the happiness of motherhood, and the family experiences the tragedy of childlessness. In this case, artificial reproductive technologies come to the aid of the family. The possibility of using them is far from indisputable. Representatives of all religious faiths believe that the birth of children must occur through the sacrament of marriage between a man and a woman. In a secular philosophy, polemics go on the issues of eligibility for manipulation on the human sex cells, their freezing, surrogate motherhood, etc. All these are open problems of bioethics.

\section{UDC 614.25:34 DOI 10.22448/AMJ.2017.4.9-11}

\section{LEGAL FOUNDATIONS OF MEDICAL PRACTICE}

\section{S. Matushenko}

Sbei HPE Amur state medical Academy of Minzdrav of Russia, Blagoveshchensk

SUMMARY the article substantiates the necessity of studying doctors theoretical ideas about the peculiarities of regulation of legal relations in the sphere of medicine and public health, the need of physicians of the legislation on health care of the Russian Federation to particular situations.

KEY WORDS: law, health, law, justice, medicine, doctor.

Legal regulation of medical activity has its origin from the time of Hammurabi, according to which doctor was responsible for causing the patient harm. Since then the law has undergone significant changes and today, the right to health protection and medical aid to the citizens in the Russian Federation elevated to constitutional rank. Of all of the elements of the system to ensure citizens ' rights to adequate medical service, the greatest change has undergone a legal and regulatory framework in the provision of medical services. A significant change has been the "bases of the legislation of the Russian Federation about health protection of citizens" (1993), changed the dispositions and sanctions of many articles of the criminal code relating to crimes against life and health of individuals and the population (1997), the new character of relations in the sphere of health protection of citizens formed with the release of a new GK (1995-1996). 